\title{
Chemopreventive and Chemotherapeutic Effect of Propolis and Its Constituents: A Mini-review
}

\author{
Hui-Fang Chiu', Yi-Chun Han ${ }^{2}$, You-Cheng Shen ${ }^{3}$, Oksana Golovinskaia ${ }^{4}$, Kamesh Venkatakrishnan ${ }^{2}$, Chin-Kun Wang ${ }^{2}$ \\ ${ }^{1}$ Department of Chinese Medicine, Taichung Hospital Ministry of Health and Well-being, ${ }^{2}$ School of Nutrition, Chung Shan Medical \\ University, ${ }^{3}$ School of Health Diet and Industry Management, Chung Shan Medical University, Taichung City, Taiwan, ROC, \\ ${ }^{4}$ Faculty of Food Biotechnologies and Engineering, ITMO University, Saint-Peterburg, Russia
}

\begin{abstract}
Propolis is a bee wax rich in various phytocomponents and traditionally used to treat various ailments. Propolis is reported to possess an array of biological properties including anti-inflammatory, antioxidant, anti-cancer, and anti-diabetic as well as cardioprotective, hepatoprotective, renoprotective, and derma protective activities. A plethora of studies confirmed that propolis is effective against various types of cancer including head and neck, lung, liver, brain (glioma), pancreas, kidney, prostate, skin (melanoma), breast, oral, esophagus, gastric, colorectal, and bladder cancers. However, many researchers have demonstrated that propolis displays potent chemoprotective/chemopreventive or anti-cancer activity against only a few types of cancers like oral, gastrointestinal, dermal (melanoma), breast, and prostate cancers. Therefore, this mini-review only summarizes the chemopreventive/chemotherapeutic activities of propolis and its updated underlying mechanisms. Taken together, propolis displays potent chemoprotective or anti-cancer effect due to the presence of various phytocomponents which contribute to pro-apoptotic, cytotoxic, anti-proliferative (cell cycle arrest), anti-metastatic, anti-invasive, anti-angiogenic and anti-genotoxic or anti-mutagenic properties along with antioxidant, immunomodulatory, and anti-inflammatory functions. Hence, propolis could be used as an adjuvant for treating various cancers along with standard chemotherapeutic drugs. However, many large-scale clinical studies are needed to justify such applications.
\end{abstract}

Key Words Propolis, Anti-cancer, Adjuvant therapy, Apoptosis, Chemotherapeutic drugs

\section{INTRODUCTION}

\section{Propolis}

Propolis (bee wax/glue) is a resinous product collected by a bee (Apis mellifera) from plants to cementing the beehives and acts as an insulating or protecting material. Propolis is rich in phytocomponents (polyphenols-flavonoids and phenolic acids) which have numerous therapeutic properties $[1,2]$. Propolis is traditionally used in the management of various abnormal or pathological conditions which include sore throat, stomach ulcer, oral mucositis, skin rashes, eczemas, bacterial/viral/fungal infection (anti-microbial), and breast cancer $[3,4]$. Currently, in the market, there are different types of propolis based on their origin. The popular propolis types are Brazilian, Taiwanese, Chinese, Okinawa, Indian, Turkish, Polish, Greece, Cuban, and African. They also differ from one another in a color (red/brown/yellow/green) and texture, depending on the origin of place (geographical) as well as climate $[5,6]$.

The composition of propolis depends on the location (plant source-phytogeography) and collection time (season/climate condition) [7]. The major components include resin (40\%-50\%), wax $(25 \%-30 \%)$, essential oils/fatty acids ( $8 \%-10 \%)$, bee pollen $(3 \%-5 \%)$, organic acids and amino acids (1\%-3\%), and vitamins and mineral (1\%) [8-10]. Propolis contains more than 300 different types of components especially polyphenols (flavonoids, flavones, flavonols, and phenolic acids). The major active components of propolis include caffeic acid phenethyl ester (CAPE), galangin, chrysin, nemorosone, propolin G, artepillin $\mathrm{C}$, cardanol, cardol, pinocembrin, pinobanksin, chicoric acid, and ohenolic acids (caffeic acid, ferulic acid, cinnamic and coumaric acid) as well as luteolin, apigenin, myricetin, naringenin, kaempferol, quercetin, polysaccharide, tannins, terpenes, sterols and aldehydes [8,11-13]. Studies have also

Received March 12, 2020, Revised May 8, 2020, Accepted May 20, 2020

Correspondence to Chin-Kun Wang, E-mail: wck@csmu.edu.tw, https://orcid.org/0000-0001-5371-7847

Check for updates

(i) \$ This is an Open Access article distributed under the terms of the Creative Commons Attribution Non-Commercial License, which permits unrestricted noncommercial use, distribution, and reproduction in any medium, provided the original work is properly cited.

Copyright @ 2020 Korean Society of Cancer Prevention 
shown that the presence of various organic acids/amino acids, vitamins ( $\mathrm{C}, \mathrm{A}, \mathrm{B}$ complex) and minerals ( $\mathrm{Ca}, \mathrm{P}, \mathrm{Mg}, \mathrm{Fe}$, $\mathrm{K}$, and $\mathrm{Si}$ ) along with the aforementioned active polyphenols makes propolis a special therapeutic as well as a health care product. Hence, propolis can be used as a functional food as well as complementary and alternative medicine $[7,14,15]$.

Ample amounts of data indicate that propolis displays an array of therapeutic functions, such as antioxidant/free-radical scavenging, anti-inflammatory, anti-microbial, anti-cancer, anti-ulcer, anti-allergic, and anti-diabetic activities as well as cardioprotective, hepatoprotective, renoprotective, and dermaprotective (wound healing) properties $[8,12,16]$. However, many scientists showed immense interest in the chemotherapeutic/chemopreventive activity of propolis due to the presence of phytonutrients which have multitargeted anti-cancer properties, such as pro-apoptotic, autophagy, cytotoxicity, anti-proliferative (cell cycle arrest), anti-migrative (antimetastatic and, anti-invasive), anti-angiogenic and anti-genotoxic or anti-mutagenic (regulate tumor suppressor genes [TSG] and oncogenes) properties along with antioxidant, immunomodulatory and anti-inflammatory functions $[10,12,17]$. The common chemopreventive or anti-cancer activities of propolis are illustrated in Figure 1. In addition, propolis is well accepted and safe for human consumption and has been approved by the US Food and Drug Administration [18]. It has been reported that propolis exhibits potent anti-cancer/chemoprotective activity in many models (cell line/animal/human) of head and neck, lung, liver, brain, pancreas, kidney, prostate, skin, breast, oral, esophagus, gastric, colon, and bladder cancers through modulation of various signaling molecules. These include COX, lipoxygenase (LOX), inducible NOS, phosphatidylinositol 3-kinase (PI3K)/protein kinase B (Akt), $\mathrm{NF}-\kappa \mathrm{B}, \mathrm{TSG}$ (p53 and p21), mitogen-activated protein kinases (MAPKs), metalloproteinases (MMPs), caspases, Bax/ Bcl2, TNF-related apoptosis-inducing ligand (TRAIL), and nuclear factor erythroid 2-related factor 2/heme oxygenase [11,16,17,19].

Propolis is reported to display potent chemoprotective activity against some malignancies like oral, gastrointesti- nal (GI), dermal (melanoma), breast, and prostate cancers $[8,10,16,20,21]$. This mini-review summarizes the chemopreventive activity of propolis and its updated detailed mechanism (based on in vitro and animal studies) with focus on the aforementioned cancers.

\section{Chemopreventive effects on oral cancer and underlying mechanisms}

Oral cancer is the most common cancer related to the head and neck cancer, which ranks the 6th frequent cancer globally. There are several types of oral cancers including oral squamous cell carcinoma (OSCC), verrucous carcinoma (VC), benign oral cavity tumor (gingiva/tongue), and minor salivary gland carcinoma. Of these, OSCC contributes to $90 \%$ to $92 \%$ of all types of oral cancer followed by VC and others. Epidemiological studies have revealed that the incidence of oral cancer is high in males than females, especially in developing countries. Moreover, Southeast Asian and Central Africans are highly prone to oral cancer due to increased consumption of chewing betel nut, smoking, and alcohol consumption [22,23]. Many researchers have inferred that propolis and its active components could considerably inhibit the proliferation of oral cancer cells, which was proven by using different cell lines like SCC15/25, CAL27, KB cells [11,18,24].

Treatment with propolis enriched with CAPE displayed potent chemotherapeutic activity by suppressing inflammatory cascade (downregulating COX-2 expression) and considerably altering immunological response (immunomodulatory activity) and subsequently suppressed the prostaglandin 2 synthesis in human oral epidermal carcinoma KB cells [11]. Anti-proliferative and cytotoxic activities were observed in various oral cancer cell lines after administration of various types of propolis and its active components [24,25]. Moreover, propolis and its components are reported to modulate cell cycle regulators like cyclin $\mathrm{D}$, cyclin-dependent kinases (Cdk)-2/4/6, and cyclin-dependent kinase inhibitors, thereby arresting the progression of cancer cell cycle (G2/M phase) [18]. Also, propolis can modulate the expression of various TSGs (p53 and Rb) as well as downregulation of oncogenes



Figure 1. The common chemopreventive or anti-cancer activity of propolis. TSG, tumor suppressor genes. 
(MIFT and K-Ras) [18,26]. Propolis also exhibits potent anti-metastatic and anti-angiogenesis properties as revealed by suppressing MMPs-2/9 activity. This was attributable to downregulation of growth factors like EGF, vascular derived growth factor via alteration of Jun N-terminal kinase, ERK1/2, $N F-\kappa B$, and Akt signaling $[21,26]$. Propolis could markedly trigger apoptosis by altering the expression of pro- and anti-apoptotic proteins as well as modulation of kinase $\mathrm{C}$ and inhibit tyrosine kinase signaling pathways [24,27]. Moreover, a study conducted by Kuo and colleagues [26] suggested that administration of CAPE would be a better adjuvant therapy in patients with OSCC as it inhibits human oral cancer TW2.6 cell proliferation and invasion/metastasis via downregulation of NF-kB and Akt signaling pathways. In 2018, Celińska-Janowicz et al. [28] reported that polyphenols present in the propolis (chrycin, coumaric acid, caffeic acid, and ferulic acid) could trigger PRODH/POX (proline degradation/proline oxidase) dependent apoptosis by modulating proline turn over (utilization and degradation) and thus affecting collagen biosynthesis in human tongue squamous CAL-27 carcinoma cells.

\section{Chemopreventive effects on GI cancers and underlying mechanisms}

$\mathrm{GI}$ cancer is a group of malignancies that affects the different organs of the digestive system. These include esophageal, gastric, liver, pancreas, gallbladder, intestinal (colorectal, duodenal), and anal cancers. As it combines many types of cancer, GI cancer is the most common form of cancer that affects both genders worldwide. The prevalence rate of GI cancer, especially colorectal cancer, is high in developing as well as developed countries [29,30]. Moreover, GI cancers are responsible for about $10 \%$ to $15 \%$ of total global cancer mortality, which is significantly higher than other types of cancer $[31,32]$. Propolis and its active components are reported to attenuate proliferation and migration (invasion) of various $\mathrm{GI}$ cell lines including HCT-15/116, HT-29, CT 26, SW-480/620, WiDr, CaCo2, AGS, KYSE-30, and NCI-N87 cell lines as well as in animal models [33,34].

Propolis shows anti-proliferative and cytotoxic activities (VEGF) in both animal and cell line models $[35,36]$. Propolis and its active ingredients can trigger both intrinsic and extrinsic apoptosis by modulating miRNA as well as via a TRAIL-dependent mechanism [34,37]. Moreover, different types of propolis and its active ingredients like genistein, chrysin, and CAPE upregulate various tumor suppressor genes like p53 as well as regulate cell cycle by modulating p21 mRNA expression, leading to induction of cell cycle arrest in the G2/M and G0/G1 phase in human colon cancer cells $[38,39]$. Brazilian propolis exerts anti-oxidant (free radical scavenging), immunomodulatory (macrophage and $T$ lymphocytes activation) and anti-inflammatory effects in the gastric cancer model by downregulating Toll-like receptor 4 (TLR-4), glycogen synthase kinase 3 beta, and NF- $\mathrm{kB}$ signal- ing pathways [40]. Propolis triggers colon cancer cell death by increasing DNA condensation which accounts for the reduced proliferation rate and induction of apoptosis $[41,42]$. Propolis exhibits strong chemoprotective activity by modulation of the glycolytic metabolism of various cancer cells in a way to lower glucose availability, resulting in lower cell proliferation [10]. Also, propolis and CAPE may directly inhibit VEGF production and thus display anti-angiogenesis as well as inhibit MMP production and thus inhibit metastasis [43]. Studies have shown that propolis and its major ingredients can induce mitochondrial dysfunction by increasing reactive oxygen species (ROS) production and thus suppress proliferation and enhance apoptosis $[44,45]$.

Skiba et al. [46], concluded that treatment with ethanolic extract of propolis (from Poland) could effectively inhibit $\mathrm{He}$ licobacter pylori-induced gastric cancer by suppressing the expression of interleukin (IL)-8 in the gastric adenocarcinoma AGS cell line. Recently, a study conducted by Jafari-Ghahfarokhi and colleagues [47] has indicated that treatment with CAPE could effectively downregulate the mRNA expression of PLD1 gene responsible for phospholipase D production involved in AGS cell growth. Based on these findings, authors recommended that propolis (CAPE) can be used as adjuvant chemotherapy for gastric cancer. Frión-Herrera et al. [48] have shown that Cuban propolis and its active component (nemorosone) can considerably abolish cell migration (metastasis and invasion) through modulation of the expression of E-cadherin, vimentin, and $\beta$-catenin in HT-29 and LoVo colorectal cell lines. Even the studies conducted in animals (rats) demonstrated that treatment with propolis and its active components can effectively suppress the tumor cell proliferation or tumor growth as well as trigger apoptosis $[35,49,50]$.

\section{Chemopreventive effects on dermal or skin cancer or melanoma and underlying mechanisms}

Skin or dermal cancer is one of the most frequent types of cancer, especially in the Caucasian population. Skin cancer is classified into two types, malignant melanoma and non-malignant melanoma both of which are caused by chronic exposure to excessive UV light. Melanoma characterized by elevated/excess melanin production in melanocytes is one of the dangerous forms of skin cancer. Its incidence has considerably increased in recent times, especially due to climate changes, occupational exposure to UV, and a modified lifestyle pattern $[51,52]$. A report from World Health Organization shows that 0.1 million people are newly diagnosed with melanoma every year, and the mortality is also climbing [53]. Similar to other sections, many studies have confirmed that propolis and its active phytocomponents display a potent chemoprotective function against skin cancer or melanoma in different cell lines and animal models [54,55].

An ample amount of experiments showed that propolis and its active compounds could display anti-proliferative, cy- 
totoxic, anti-angiogenic, and immunomodulatory activities in various skin cancer or melanoma cell line [41,56,57]. Propolis can inhibit MMPs and trigger apoptosis, cell cycle arrest and autophagy by targeting the NLRP1 inflammatory signaling pathway [54,58]. Ozturk et al. [55] pointed out that the administration of propolis could suppress the production of pro-inflammatory cytokines as well as enhance the production of anti-inflammatory cytokines (IL-10) in the melanoma cell line. Zhang et al. [59], have demonstrated that propolis and its active components (galagin) initiate apoptosis and induce mitochondrial membrane potential loss through upregulating p38 mitogen-activated protein kinase (MAPK) and p62 as well as down-regulate tyrosinase activity (anti-melanogenesis) by modulating microphthalmia-associated transcription factor in B16F10 melanoma cells. Moreover, chrysin (an active ingredient of propolis) effectively stimulates apoptosis (Bax activation) by upregulating p38 MAPK and downregulating the ERK1/2 signaling pathway in A375 and B16-F1 melanoma cell lines [60]. Few animal studies also confirmed the chemotherapeutic properties of propolis against various skin cancer by inhibiting tumor proliferation as well as by triggering apoptosis and autophagy $[36,61]$.

\section{Chemopreventive on breast cancer and underlying mechanisms}

Breast cancer is one of the common forms of malignancy in females, which contributes to almost half a million death every year. Also, the probability of developing breast cancer was increasing in recent times [62,63]. Statistical and epidemiological studies have shown that breast cancer prevalence among Asian and African women is significantly lower than Hispanic women. In addition, breast cancer incidence rates were also increasing in post-menopausal women than young women due to hormonal involvement $[64,65]$. Various breast cancer cell lines (MCF-7, MDA-MB-231, BT-474, and T47D-estrogen receptor) are used to examine the chemoprotective activity of propolis and its active components. Results are convincing as both crude extract of propolis as well as its active phytocomponents showed strong chemoprotective or anti-cancer activity in various cell lines [66,67].

Ethanolic extract of propolis and its active components (CAPE) are reported to exhibit antioxidant, cytotoxic, pro-apoptotic, autophagic, and anti-inflammatory activities in lipopolysaccharide stimulated MDA-MB-231 breast cancer cells by suppressing the TLR-4 signaling pathway [6870]. Frión-Herrera and colleagues [71] demonstrated that treatment of breast cancer cells with propolis and its active ingredient (cardanol) triggered apoptosis (cytotoxicity) by modulation of PI3K/Akt, p38 MAPK, and ERK1/2 signaling pathways as well as by enhancing ROS generation and subsequent loss of mitochondrial potential. Propolis displays strong anti-proliferative and induces cell cycle arrest (G0/G1 and G2/M phase) by upregulating p21 and p27 expression [72]. Lately, Misir et al. [73] have demonstrated that Turkish propolis markedly alters the miRNA expression of tumor suppressors gene ( $\mathrm{miR} 34,15 a$, and 16-5p) as well as miR 21 and breast cancer gene (BRCA 1/2) in human breast cancer MCF-7 cells. Many studies have shown that propolis and its components can exert immunomodulatory (macrophage and Natural killer activation), anti-angiogenic (inhibit VEGF) and anti-metastatic properties in the breast cancer cell line model [10]. Jung et al. [74] have indicated that propolis and CAPE can effectively modulate estrogen receptor in MCF 7 and MDA 231 breast cancer cell lines. CAPE can potentially inhibit invasion/metastasis and cell motility in human breast cancer cells through blockage of voltage-gated sodium channels [75]. Moreover, a clinical study confirmed that propolis can effectively prevent oral mucositis in patients with breast cancer, who received doxorubicin and cyclophosphamide (chemotherapy). The above study indicates that propolis can also suppress the adverse events caused during chemotherapy and thus has its palliative property [76].

\section{Chemopreventive on prostate cancer and underlying mechanisms}

Prostate cancer is the fifth most common cancer globally (second most common in men), and its prevalence rate is increasing significantly in recent times especially in western countries. Prostate cancer is the second leading cause of death from cancer owing to its high metastasis rate, which accounts for $4 \%$ of all global cancer death rates. It is an androgen-dependent tumor but progresses very slowly without any notable symptoms $[16,77]$. The incidence of prostate cancer is higher in Caucasians than Asians, but the mortality rates are higher in black than white population [78]. Moreover, prostate cancer cells are highly resistant to apoptosis and autophagy. Hence, treating the prostate cancer cells is quite hard and thus a new therapeutic strategy should be developed by focusing more on anti-inflammatory and antioxidative drugs. Existing evidence has conferred that propolis and its active components can strongly suppress the proliferation and migration as well as enhance apoptosis in various prostate cancer cell lines like LNCaP, PC-3, PANC-1, and DU-145 [77,79].

Propolis and its components display strong anti-proliferative activity via suppression of proliferating cell nuclear antigen and vascular cell adhesion molecule 1 in human prostate PC-3 cancer cells [80]. Also, propolis supplementation could significantly arrest the cell cycle in prostate cancer cells by modulation of the expression of cyclin A, B, and D1, and Cdk as well as p21 [79,81]. Moreover, propolis can induce apoptosis by decreasing the cellular levels of apoptosis inhibitor proteins including cellular inhibitor apoptosis protein 1/2 (clAP$1 / 2)[81,82]$. Meanwhile, Szliszka et al. [83] reported that the treatment with propolis (apigenin, galangin, CAPE, and kaempferin) significantly improved TRAIL (death receptor)-medicated apoptosis in prostate cancer cells. Propolis and its derivatives (chrysin and CAPE) were proven to enhance 
apoptosis of androgen-independent prostate cancer cells (PC-3) by increasing ROS production as well as suppressed their proliferation by down-regulating ERK $1 / 2$ and PI3K/Akt signaling $[84,85]$.

Ozturk and his colleagues [55] have reported that propolis and its active ingredients can suppress ROS production due to antioxidant and anti-inflammatory activities associated with suppression of COX-2/LOX and NF-kB signaling. Moreover, this study demonstrated that propolis possessing $5-\alpha$ reductase inhibitory activity effectively inhibited prostate cancer cell proliferation. Propolis and its components (genistein) were reported to enhance expression of TSGs, such as p53 and $\mathrm{p} 16$ as well as demethylation of $\mathrm{p} 16$ and MGMT genes in various prostate cancer cell lines [86]. CAPE has been reported to inhibit prostate cancer cell invasion and metastasis through activation of the non-canonical Wnt-signaling pathway [87]. CAPE can synergistically act with docetaxel and paclitaxel (standard chemotherapeutic drugs) and significantly decrease cell proliferation by triggering cell cycle arrest and subsequently initiating apoptosis in PC-3 prostate cancer cells [86].

\section{Clinical studies and adjuvant therapy of propolis}

Propolis and its active components have potent chemotherapeutic properties in various cancer cells and in animal studies. However, only few clinical trials have been conducted with propolis and its active components against limited cancer conditions (polyp), but the results are not convincing $[88,89]$. Moreover, propolis has poor bioavailability owing to low water solubility and hence can be delivered using nanoparticles (carriers-Ag-silica/Au) or by encapsulation [89], which might enhance the chemopreventive activity. Many studies have confirmed that propolis (safe and well-tolerated) can be recommended as an adjuvent agent against various cancers as it might potentiate either standard chemotherapy or radiotherapy (palliative) while suppressing the adverse effects induced by the standard chemotherapeutic drugs $[10,76,88,89]$. Figure 2 illustrates the in-depth chemopreventive or anti-cancer effects of propolis and its components against oral, GI, skin, breast, and prostate cancers.

\section{CONCLUSION AND FUTURE PROSPECTIVE}

Overall, this mini-review highlights the chemopreventive and chemotherapeutic activities of propolis and its detailed mechanism against oral, dermal/skin (melanoma), breast, prostate and GI cancers. Propolis displays potent chemoprotective effects due to the presence of various phytocomponents (CAPE, galangin, chrysin, artepillins $\mathrm{C}$, and nemorosone) which contributes to pro-apoptotic, cytotoxicity, anti-proliferative, anti-angiogenic and anti-genotoxic properties along with antioxidant, immunomodulatory and anti-inflammatory functions. Therefore, propolis might be recommended for
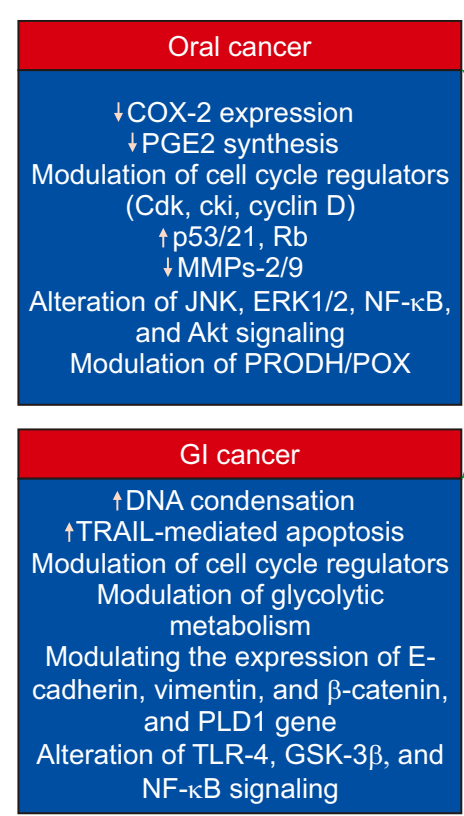

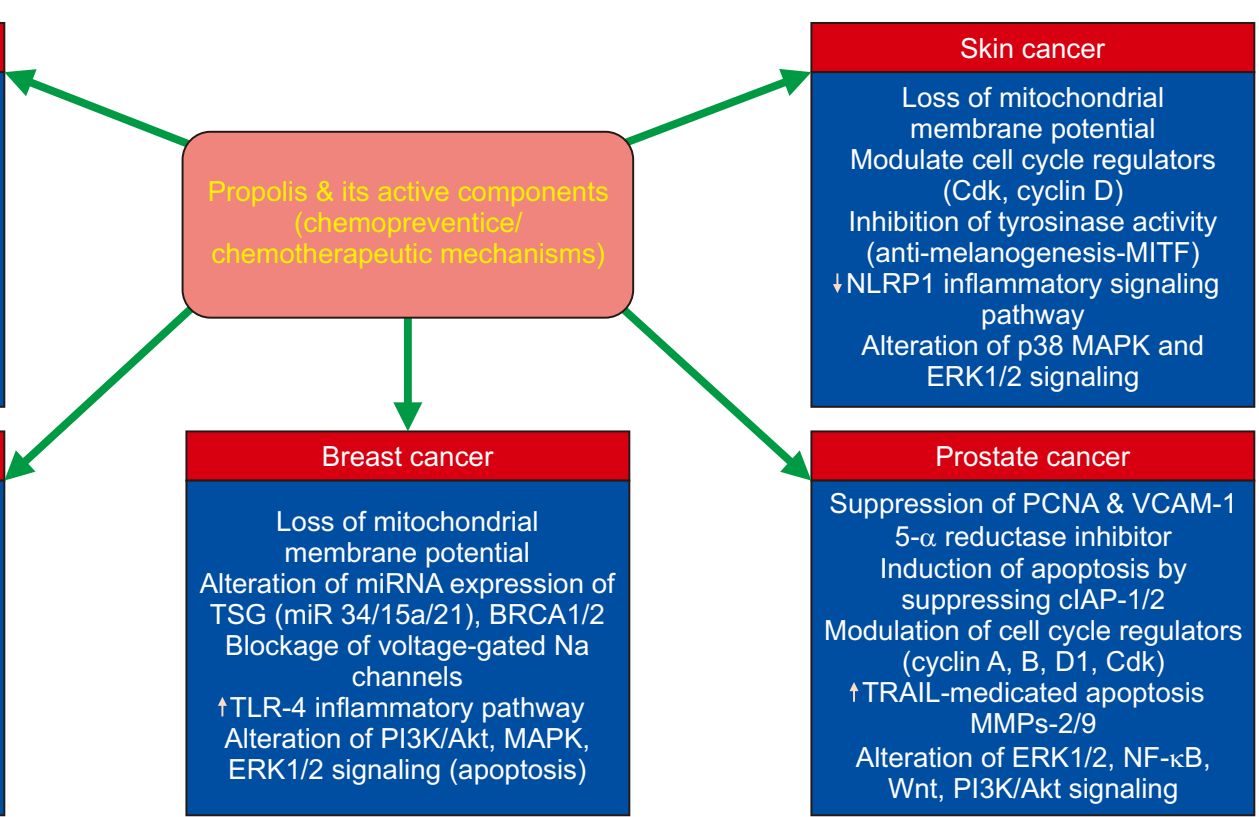

Figure 2. The in-depth chemopreventive or anti-cancer effect of propolis and its components against oral, gastrointestinal (GI), skin, breast, and prostate cancers. PGE, prostaglandin 2; Cdk, cyclin-dependent kinases; cki, cyclin-dependent kinase inhibitors; MMPs, metalloproteinases; JNK, Jun N-terminal kinase; PRODH/POX, proline degradation/proline oxidase; MITF, microphthalmia-associated transcription factor; MAPK, mitogen-activated protein kinase; TRAIL, TNF-related apoptosis-inducing ligand; TLR-4, Toll-like receptor 4; GSK-3 $\beta$, glycogen synthase kinase 3 beta; TSG, tumor suppressor genes; BRCA, breast cancer genes; PI3K, phosphatidylinositol 3-kinase; PCNA, proliferating cell nuclear antigen; VCAM-1, vascular cell adhesion molecule; cIAP-1/2, cellular inhibitor apoptosis protein 1/2. 
adjuvant therapy along with conventional chemotherapeutic drugs to either potentiate their efficacy or to minimize adverse effects. However, many large-scale clinical studies should be conducted with crude propolis extract and its active components (individually or mixture at different ratios) to validate their use in human populations.

\section{CONFLICTS OF INTEREST}

No potential conflicts of interest were disclosed.

\section{ORCID}

Hui-Fang Chiu, https://orcid.org/0000-0001-8929-9907

Yi-Chun Han, https://orcid.org/0000-0002-6104-7799

You-Cheng Shen, https://orcid.org/0000-0002-3098-4712

Oksana Golovinskaia, https://orcid.org/0000-0001-6444-0118

Kamesh Venkatakrishnan, https://orcid.org/0000-0002-8498-7089 Chin-Kun Wang, https://orcid.org/0000-0001-5371-7847

\section{REFERENCES}

1. Yumnam R, Nandan N, Kumar NC, Raj S, Mannepalli A. Effect of propolis in oral health. J Ayurveda Integr Med Sci 2017;2:18692.

2. Pasupuleti VR, Sammugam L, Ramesh N, Gan SH. Honey, propolis, and royal jelly: a comprehensive review of their biological actions and health benefits. Oxid Med Cell Longev 2017;2017:1259510.

3. Sforcin JM, Bankova V, Kuropatnicki AK. Medical benefits of honeybee products. Evid Based Complement Alternat Med 2017;2017:2702106.

4. Sforcin JM. Propolis and the immune system: a review. J Ethnopharmacol 2007;113:1-14.

5. Pobiega K, Gniewosz M, Kraśniewska K. Antimicrobial and antiviral properties of different types of propolis. Zesz Probl Postęp Nauk Rol 2017;589:69-79.

6. Bankova V. Recent trends and important developments in propolis research. Evid Based Complement Alternat Med 2005;2:29-32.

7. Yen $\mathrm{CH}$, Chiu HF, Wu CH, Lu YY, Han YC, Shen YC, et al. Beneficial efficacy of various propolis extracts and their digestive products by in vitro simulated gastrointestinal digestion. LWT 2017;84:281-9.

8. Anjum $\mathrm{SI}$, Ullah A, Khan KA, Attaullah M, Khan $\mathrm{H}$, Ali $\mathrm{H}$, et al. Composition and functional properties of propolis (bee glue): a review. Saudi J Biol Sci 2019;26:1695-703.

9. Bueno-Silva B, Marsola A, Ikegaki M, Alencar SM, Rosalen PL. The effect of seasons on Brazilian red propolis and its botanical source: chemical composition and antibacterial activity. Nat Prod Res 2017;31:1318-24.

10. Patel S. Emerging adjuvant therapy for cancer: propolis and its constituents. J Diet Suppl 2016;13:245-68.

11. Chiu HF, Yang CS, Chi HI, Han YC, Shen YC, Venkatakrishnan
$\mathrm{K}$, et al. Cyclooxygenase-2 expression in oral precancerous and cancerous conditions and its inhibition by caffeic acid phenyl ester-enriched propolis in human oral epidermal carcinoma KB cells. Arch Biol Sci 2017;69:83-91.

12. Hashemi JM. Biological effect of bee propolis: a review. Eur $\mathrm{J}$ Appl Sci 2016;8:311-8.

13. Bae YJ, Lee EJ, Kang MH, Kwon OR, Kim MK, Sung MK. Effect of propolis intake on antioxidative capacity in rats fed high fat diet. Cancer Prev Res 2010;15:143-51.

14. Kuropatnicki AK, Szliszka E, Krol W. Historical aspects of propolis research in modern times. Evid Based Complement Alternat Med 2013;2013:964149.

15. Khalil ML. Biological activity of bee propolis in health and disease. Asian Pac J Cancer Prev 2006;7:22-31.

16. Zabaiou N, Fouache A, Trousson A, Baron S, Zellagui A, Lahouel $M$, et al. Biological properties of propolis extracts: something new from an ancient product. Chem Phys Lipids 2017;207(Pt B):21422.

17. Sawicka D, Car H, Borawska MH, Nikliński J. The anticancer activity of propolis. Folia Histochem Cytobiol 2012;50:25-37.

18. Saarem W, Wang FY, Farfel E. Propolis or caffeic acid phenethyl ester (CAPE) inhibits growth and viability in multiple oral cancer cell lines. Int J Med Biomed Stud 2019;3:50-5.

19. Oršolić N. A review of propolis antitumour action in vivo and in vitro. J ApiProd ApiMed Sci 2010;2:1-20.

20. Turan I, Demir S, Misir S, Kilinc K, Mentese A, Aliyazicioglu $Y$, et al. Cytotoxic effect of Turkish propolis on liver, colon, breast, cervix and prostate cancer cell lines. Trop J Pharm Res 2015; 14:777-82.

21. Hwu YJ, Lin FY. Effectiveness of propolis on oral health: a metaanalysis. J Nurs Res 2014;22:221-9.

22. García-Martín JM, Varela-Centelles P, González M, SeoaneRomero JM, Seoane J, García-Pola MJ. Epidemiology of oral cancer. In: Panta P, ed. Oral Cancer Detection. Cham, Springer, pp 81-93, 2019.

23. Conway DI, Purkayastha M, Chestnutt IG. The changing epidemiology of oral cancer: definitions, trends, and risk factors. Br Dent J 2018;225:867-73.

24. Yu HJ, Shin JA, Yang IH, Won DH, Ahn CH, Kwon HJ, et al. Apoptosis induced by caffeic acid phenethyl ester in human oral cancer cell lines: involvement of Puma and Bax activation. Arch Oral Biol 2017;84:94-9.

25. Dziedzic A, Kubina R, Kabała-Dzik A, Wojtyczka RD, Morawiec T, Bułdak RJ. Caffeic acid reduces the viability and migration rate of oral carcinoma cells (SCC-25) exposed to low concentrations of ethanol. Int J Mol Sci 2014;15:18725-41.

26. Kuo YY, Lin HP, Huo C, Su LC, Yang J, Hsiao PH, et al. Caffeic acid phenethyl ester suppresses proliferation and survival of TW2.6 human oral cancer cells via inhibition of Akt signaling. Int J Mol Sci 2013;14:8801-17.

27. Czyżewska U, Siemionow K, Zaręba I, Miltyk W. Proapoptotic activity of propolis and their components on human tongue squamous cell carcinoma cell line (CAL-27). PLoS One 2016;11:e0157091. 
28. Celińska-Janowicz K, Zaręba I, Lazarek U, Teul J, Tomczyk $\mathrm{M}$, Pałka J, et al. Constituents of propolis: chrysin, caffeic acid, p-coumaric acid, and ferulic acid induce PRODH/POXdependent apoptosis in human tongue squamous cell carcinoma cell (CAL-27). Front Pharmacol 2018;9:336.

29. Murphy N, Jenab M, Gunter MJ. Adiposity and gastrointestinal cancers: epidemiology, mechanisms and future directions. Nat Rev Gastroenterol Hepatol 2018;15:659-70.

30. Prasad S, Tyagi AK. Ginger and its constituents: role in prevention and treatment of gastrointestinal cancer. Gastroenterol Res Pract 2015;2015:142979.

31. Pourhoseingholi MA, Vahedi M, Baghestani AR. Burden of gastrointestinal cancer in Asia; an overview. Gastroenterol Hepatol Bed Bench 2015;8:19-27.

32. Herszényi L, Tulassay Z. Epidemiology of gastrointestinal and liver tumors. Eur Rev Med Pharmacol Sci 2010;14:249-58.

33. Catchpole O, Mitchell K, Bloor S, Davis P, Suddes A. Antiproliferative activity of New Zealand propolis and phenolic compounds vs human colorectal adenocarcinoma cells. Fitoterapia 2015;106:167-74.

34. Ishihara M, Naoi K, Hashita M, Itoh Y, Suzui M. Growth inhibitory activity of ethanol extracts of Chinese and Brazilian propolis in four human colon carcinoma cell lines. Oncol Rep 2009;22:34954.

35. Doi K, Fujioka M, Sokuza Y, Ohnishi M, Gi M, Takeshita M, et al. Chemopreventive action by ethanol-extracted Brazilian green propolis on post-initiation phase of inflammation-associated rat colon tumorigenesis. In Vivo 2017;31:187-97.

36. Watanabe MA, Amarante MK, Conti BJ, Sforcin JM. Cytotoxic constituents of propolis inducing anticancer effects: a review. J Pharm Pharmacol 2011;63:1378-86.

37. Kumazaki M, Shinohara H, Taniguchi K, Yamada N, Ohta S, Ichihara K, et al. Propolis cinnamic acid derivatives induce apoptosis through both extrinsic and intrinsic apoptosis signaling pathways and modulate of miRNA expression. Phytomedicine 2014;21:1070-7.

38. Zhang Z, Wang CZ, Du GJ, Qi LW, Calway T, He TC, et al. Genistein induces G2/M cell cycle arrest and apoptosis via ATM/ p53-dependent pathway in human colon cancer cells. Int J Oncol 2013;43:289-96.

39. Shimizu K, Das SK, Hashimoto T, Sowa Y, Yoshida T, Sakai T, et al. Artepillin $C$ in Brazilian propolis induces $G(0) / G(1)$ arrest via stimulation of Cip1/p21 expression in human colon cancer cells. Mol Carcinog 2005;44:293-9.

40. da Silva LM, de Souza P, Jaouni SKA, Harakeh S, Golbabapour $S$, de Andrade SF. Propolis and its potential to treat gastrointestinal disorders. Evid Based Complement Alternat Med 2018;2018:2035820.

41. Kubina R, Kabała-Dzik A, Dziedzic A, Bielec B, Wojtyczka RD, Bułdak RJ, et al. The ethanol extract of Polish propolis exhibits anti-proliferative and/or pro-apoptotic effect on HCT 116 colon cancer and Me45 malignant melanoma cells in vitro conditions. Adv Clin Exp Med 2015;24:203-12.

42. de Lima RO, Bazo AP, Said RA, Sforcin JM, Bankova V, Darros
BR, et al. Modifying effect of propolis on dimethylhydrazineinduced DNA damage but not colonic aberrant crypt foci in rats. Environ Mol Mutagen 2005;45:8-16.

43. Liao HF, Chen YY, Liu JJ, Hsu ML, Shieh HJ, Liao HJ, et al. Inhibitory effect of caffeic acid phenethyl ester on angiogenesis, tumor invasion, and metastasis. J Agric Food Chem 2003;51:7907-12.

44. Kustiawan PM, Lirdprapamongkol K, Palaga T, Puthong S, Phuwapraisirisan P, Svasti J, et al. Molecular mechanism of cardol, isolated from Trigona incisa stingless bee propolis, induced apoptosis in the SW620 human colorectal cancer cell line. BMC Pharmacol Toxicol 2017;18:32.

45. Ha TK, Kim ME, Yoon JH, Bae SJ, Yeom J, Lee JS. Galangin induces human colon cancer cell death via the mitochondrial dysfunction and caspase-dependent pathway. Exp Biol Med (Maywood) 2013;238:1047-54.

46. Skiba M, Szliszka E, Kunicka MA, Krol W. Effect of ethanol extract of propolis (EEP) on interleukin 8 release by human gastric adenocarcinoma cells (AGS) infected with Helicobacter pylori. Cent Eur J Immunol 2011;36:65-9.

47. Jafari-Ghahfarokhi $H$, Jazaeri A, Amini-Sarteshnizi N, Teimori $H$. The impact of caffeic acid phenethyl ester, chrysin and ethanolic extracts of propolis on PLD1 gene expression in AGS cell line. J Herbmed Pharmacol 2019;8:308-13.

48. Frión-Herrera Y, Gabbia D, Scaffidi M, Zagni L, Cuesta-Rubio O, De Martin S, et al. The Cuban propolis component nemorosone inhibits proliferation and metastatic properties of human colorectal cancer cells. Int J Mol Sci 2020;21:1827.

49. Alizadeh AM, Afrouzan H, Dinparast-Djadid N, Sawaya AC, Azizian S, Hemmati HR, et al. Chemoprotection of MNNGinitiated gastric cancer in rats using Iranian propolis. Arch Iran Med 2015;18:18-23.

50. Bazo AP, Rodrigues MA, Sforcin JM, de Camargo JL, Ribeiro LR, Salvadori DM. Protective action of propolis on the rat colon carcinogenesis. Teratog Carcinog Mutagen 2002;22:183-94.

51. Whiteman DC, Green AC, Olsen CM. The growing burden of invasive melanoma: projections of incidence rates and numbers of new cases in six susceptible populations through 2031. J Invest Dermatol 2016;136:1161-71.

52. Apalla Z, Nashan D, Weller RB, Castellsagué X. Skin cancer: epidemiology, disease burden, pathophysiology, diagnosis, and therapeutic approaches. Dermatol Ther (Heidelb) 2017;7(Suppl 1):5-19.

53. Godar DE, Subramanian M, Merrill S. Cutaneous malignant melanoma incidences analyzed worldwide by skin type over advancing age of males and females: evidence estrogen and androgenic hair are risk factors. J Epidemiol Res 2017;3:42-50.

54. Zheng Y, Wu Y, Chen X, Jiang X, Wang K, Hu F. Chinese propolis exerts anti-proliferation effects in human melanoma cells by targeting NLRP1 inflammatory pathway, inducing apoptosis, cell cycle arrest, and autophagy. Nutrients 2018;10:1170.

55. Ozturk G, Ginis Z, Akyol S, Erden G, Gurel A, Akyol O. The anticancer mechanism of caffeic acid phenethyl ester (CAPE): review of melanomas, lung and prostate cancers. Eur Rev Med 
Pharmacol Sci 2012;16:2064-8.

56. Pelinson LP, Assmann CE, Palma TV, da Cruz IBM, Pillat MM, Mânica A, et al. Antiproliferative and apoptotic effects of caffeic acid on SK-Mel-28 human melanoma cancer cells. Mol Biol Rep 2019;46:2085-92.

57. Kudugunti SK, Vad NM, Whiteside AJ, Naik BU, Yusuf MA, Srivenugopal KS, et al. Biochemical mechanism of caffeic acid phenylethyl ester (CAPE) selective toxicity towards melanoma cell lines. Chem Biol Interact 2010;188:1-14.

58. Benguedouar L, Lahouel M, Gangloff SC, Durlach A, Grange $F$, Bernard $\mathrm{P}$, et al. Ethanolic extract of Algerian propolis and galangin decreased murine melanoma tumor progression in mice. Anticancer Agents Med Chem 2016;16:1172-83.

59. Zhang W, Lan Y, Huang Q, Hua Z. Galangin induces B16F10 melanoma cell apoptosis via mitochondrial pathway and sustained activation of p38 MAPK. Cytotechnology 2013;65:44755.

60. Pichichero E, Cicconi R, Mattei M, Canini A. Chrysin-induced apoptosis is mediated through p38 and Bax activation in B16-F1 and A375 melanoma cells. Int J Oncol 2011;38:473-83.

61. Benguedouar L, Lahouel M, Gangloff S, Durlach A, Grange $F$, Bernard $P$, et al. Algerian ethanolic extract of propolis and galangin decreased melanoma tumour progression in C57BL6 mice. Ann Dermatol Venereol 2015;142:S294.

62. Rojas K, Stuckey A. Breast cancer epidemiology and risk factors. Clin Obstet Gynecol 2016;59:651-72.

63. Power EJ, Chin ML, Haq MM. Breast cancer incidence and risk reduction in the Hispanic population. Cureus 2018;10:e2235.

64. DeSantis CE, Ma J, Gaudet MM, Newman LA, Miller KD, Goding Sauer A, et al. Breast cancer statistics, 2019. CA Cancer J Clin 2019;69:438-51.

65. Krieger N, Quesenberry C Jr, Peng T, Horn-Ross P, Stewart $\mathrm{S}$, Brown $\mathrm{S}$, et al. Social class, race/ethnicity, and incidence of breast, cervix, colon, lung, and prostate cancer among Asian, Black, Hispanic, and White residents of the San Francisco Bay Area, 1988-92 (United States). Cancer Causes Control 1999;10:525-37.

66. Kabała-Dzik A, Rzepecka-Stojko A, Kubina R, Iriti M, Wojtyczka $\mathrm{RD}$, Buszman $\mathrm{E}$, et al. Flavonoids, bioactive components of propolis, exhibit cytotoxic activity and induce cell cycle arrest and apoptosis in human breast cancer cells MDA-MB-231 and MCF-7 - a comparative study. Cell Mol Biol (Noisy-le-grand) 2018;64:1-10.

67. Xuan H, Li Z, Yan H, Sang Q, Wang K, He Q, et al. Antitumor activity of Chinese propolis in human breast cancer MCF-7 and MDA-MB-231 cells. Evid Based Complement Alternat Med 2014;2014:280120.

68. Chang H, Wang Y, Yin X, Liu X, Xuan H. Ethanol extract of propolis and its constituent caffeic acid phenethyl ester inhibit breast cancer cells proliferation in inflammatory microenvironment by inhibiting TLR4 signal pathway and inducing apoptosis and autophagy. BMC Complement Altern Med 2017;17:471.

69. Vukovic NL, Obradovic AD, Vukic MD, Jovanovic D, Djurdjevic
PM. Cytotoxic, proapoptotic and antioxidative potential of flavonoids isolated from propolis against colon (HCT-116) and breast (MDA-MB-231) cancer cell lines. Food Res Int 2018;106:71-80.

70. Ozdal T, Sari-Kaplan G, Mutlu-Altundag E, Boyacioglu D, Capanoglu E. Evaluation of Turkish propolis for its chemical composition, antioxidant capacity, anti-proliferative effect on several human breast cancer cell lines and proliferative effect on fibroblasts and mouse mesenchymal stem cell line. J Apic Res 2018;57:627-38.

71. Frión-Herrera Y, Díaz-García A, Ruiz-Fuentes J, RodríguezSánchez H, Sforcin JM. The cytotoxic effects of propolis on breast cancer cells involve PI3K/Akt and ERK1/2 pathways, mitochondrial membrane potential, and reactive oxygen species generation. Inflammopharmacology 2019;27:1081-9.

72. Buahorm S, Puthong S, Palaga T, Lirdprapamongkol K, Phuwapraisirisan P, Svasti J, et al. Cardanol isolated from Thai Apis mellifera propolis induces cell cycle arrest and apoptosis of BT-474 breast cancer cells via p21 upregulation. Daru 2015;23:55.

73. Misir S, Aliyazicioglu Y, Demir S, Turan I, Hepokur C. Effect of Turkish propolis on miRNA expression, cell cycle, and apoptosis in human breast cancer (MCF-7) cells. Nutr Cancer 2020;72:13345.

74. Jung BI, Kim MS, Kim HA, Kim D, Yang J, Her S, et al. Caffeic acid phenethyl ester, a component of beehive propolis, is a novel selective estrogen receptor modulator. Phytother Res 2010;24:295-300.

75. Fraser SP, Hemsley F, Djamgoz MBA. Caffeic acid phenethyl ester: inhibition of metastatic cell behaviours via voltage-gated sodium channel in human breast cancer in vitro. Int $\mathrm{J}$ Biochem Cell Biol 2016;71:111-8.

76. Piredda M, Facchinetti G, Biagioli V, Giannarelli D, Armento G, Tonini G, et al. Propolis in the prevention of oral mucositis in breast cancer patients receiving adjuvant chemotherapy: a pilot randomised controlled trial. Eur J Cancer Care 2017;26:e12757.

77. Tseng JC, Lin CY, Su LC, Fu HH, Yang SD, Chuu CP. CAPE suppresses migration and invasion of prostate cancer cells via activation of non-canonical Wnt signaling. Oncotarget 2016;7:38010-24.

78. Krstev S, Knutsson A. Occupational risk factors for prostate cancer: a meta-analysis. J Cancer Prev 2019;24:91-111.

79. Rouibah H, Kebsa W, Lahouel M, Zihlif M, Ahram M, Aburmeleih $\mathrm{B}$, et al. Algerian propolis potentiates doxorubicin mediated anticancer effect against human pancreatic PANC-1 cancer cell line through cell cycle arrest, apoptosis induction and P-glycoprotein inhibition. Anticancer Agents Med Chem 2018;18:375-87.

80. Qiu W, Lei YH, Su M, Li DJ, Zhang N, Shen YQ. Kaempferol inhibits proliferation of human prostate cancer PC-3 cells via down-regulation of PCNA and VCAM-1. Chin Pharmacol Bull 2011;4:553-7.

81. Li H, Kapur A, Yang JX, Srivastava S, McLeod DG, ParedesGuzman JF, et al. Antiproliferation of human prostate cancer cells 
by ethanolic extracts of Brazilian propolis and its botanical origin. Int J Oncol 2007;31:601-6.

82. McEleny K, Coffey R, Morrissey C, Fitzpatrick JM, Watson RW. Caffeic acid phenethyl ester-induced PC-3 cell apoptosis is caspase-dependent and mediated through the loss of inhibitors of apoptosis proteins. BJU Int 2004;94:402-6.

83. Szliszka E, Czuba ZP, Bronikowska J, Mertas A, Paradysz A, Krol W. Ethanolic extract of propolis augments TRAIL-induced apoptotic death in prostate cancer cells. Evid Based Complement Alternat Med 2011;2011:535172.

84. Ryu S, Lim W, Bazer FW, Song G. Chrysin induces death of prostate cancer cells by inducing ROS and ER stress. J Cell Physiol 2017;232:3786-97.

85. Chuu CP, Lin HP, Ciaccio MF, Kokontis JM, Hause RJ Jr, Hiipakka RA, et al. Caffeic acid phenethyl ester suppresses the proliferation of human prostate cancer cells through inhibition of
p70S6K and Akt signaling networks. Cancer Prev Res (Phila) 2012;5:788-97.

86. Fang M, Chen D, Yang CS. Dietary polyphenols may affect DNA methylation. J Nutr 2007;137(1 Suppl):223S-8S.

87. Tolba MF, Esmat A, Al-Abd AM, Azab SS, Khalifa AE, Mosli $\mathrm{HA}$, et al. Caffeic acid phenethyl ester synergistically enhances docetaxel and paclitaxel cytotoxicity in prostate cancer cells. IUBMB Life 2013;65:716-29.

88. Sepúlveda C, Núñez O, Torres A, Guzmán L, Wehinger S. Antitumor activity of propolis: recent advances in cellular perspectives, animal models and possible applications. Food Rev Int 2020;36:429-55.

89. Kuo CC, Wang RH, Wang HH, Li CH. Meta-analysis of randomized controlled trials of the efficacy of propolis mouthwash in cancer therapy-induced oral mucositis. Support Care Cancer 2018;26:4001-9. 